\title{
Islet and Beta Cell Volumes in Offspring of Severely Diabetic (Ketotic) Chinese Hamsters
}

\author{
Anna-Mary Carpenter*, George C. Gerritsen, W.E. Dulin and Arnold Lazarow*
}

Anatomy Department*, University of Minnesota, Minneapolis, Minnesota and the Upjohn Company, Kalamazoo, Michigan

Summary. Chinese hamsters bred at the Upjohn Laboratory were studied at varying ages from 15 days to 19 months. Diabetic animals three to six months and those 10 to 19 months of age were glycosuric and hyperglycemic; there was ketonuria and ketonemia but blood glycerol and fasting plasma insulin levels were low when these values were compared with normal control animals of comparable ages. Using quantitative technics developed in our laboratory, the volumes of islets, beta cells and beta granules were diminished. The increase in volume of nongranular cells is progressive with duration of diabetes. Glycogen infiltration was observed in beta cells of these diabetic animals. - Although offspring (fifteen-day-old weanlings) of the mating of two severely diabetic (ketotic) animals were normoglycemic and glycosuric, their plasma insulin levels were higher than those of their controls. The islet volume was somewhat higher than that of the controls but the beta cells were degranulated both by light and electron microscopy; the beta cells exhibited glycogen infiltration. These results are consistent with the thesis that the primary defect is in insulin biosynthe. sis.

Le volume des îlots de Langerhans et des cellules $B$ du pancréas de la progéniture de harnsters chinois sévèrement diabetiques

Résumé. Des hamsters chinois provenant de la colonie des Laboratoires Upjohn ont été étudiés à différents âges allant de 15 jours à 19 mois. On trouve une glycosurie et une hyperglycémie chez les animaux diabétiques de 3 à 6 mois et chez ceux de 10 à 19 mois. On observe également une cétonurie et une cétonémie, mais les taux de glycérol sanguin et les taux d'insuline plasmatique à jeun sont bas par comparaison à ceux détectés chez des témoins d'âge comparable. Le volume des îlots, des cellules $\beta$ et des granules $\beta$, mesuré par des méthodes quantitatives élaborées dans notre laboratoire, est diminué. Le volume des cellules non-granulées augmente progressivement avec la durée du diabète. On observe une infiltration de gly. cogène dans les cellules $\mathbf{B}$ des animaux diabétiques. Bien que la progéniture, âgée de 15 jours, de deux animaux sévèrement diabétiques (avec cétose) ait des taux normaux de glycémie et une glycosurie, leur insulinémie est plus élevée que celle mesurée chez les témoins. Le volume de leurs îlots est un peu plus grand que celui des contrôles, mais, en microscopie optique et électronique, les cellules $\beta$ sont dégranulées et montrent une infiltration de glycogène. Ces résultats confirment l'hypothèse que le défaut primaire est au niveau de la biosynthèse de l'insuline.

Insel-und B-Zell-Volumen im Pankreas von Nachkommen schwer diabetischer chinesischer Hamster

Zusammenfassung. Mit von den Autoren entwickelten morphometrischen Methoden wurde das B-Zell-Volumen im Pankreas chinesischer Hamster der Upjohn Kolonie bestimmt. Das Alter der untersuchten Tiere schwankte zwischen 15 Tagen und 19 Monaten. Die diabetischen Tiere waren entweder $3-6$ oder $10-19$ Monate alt. Sie waren hyperglykämisch und glykosurisch, teilweise bestand Ketonurie. Dio Plasmainsulin- und GlyzerinKonzentrationen im Gesamtblut waren niedriger als diejenigen gleichaltriger Normaltieren erniedrigt. Bei diabetischen Tieren waren B-Zell- und $\beta$-Granula-Volumen vermindert. Mit zunehmender Dauer des Diabetes nahm der Anteil der nicht granulierten B-Zellen zu. Die B-Zellen diabetischer Tiere zeigten Glykogeninfiltration. 15 Tage alte Nachkommen zweier ketotisch-diabetischer Eltern waren normoglykämisch, hatten aber im Vergleich $\mathrm{zu}$ gleichaltrigen Kontrolltieren erhöhte Plasmainsulin-Konzentrationen. Das Inselzellvolumen war gegenüber der Norm erhöht, aber die B-Zellen waren degranuliert und zeigten Glykogeninfiltration. Diese Resultate stimmen mit der Hypothese überein, daß der primäre Defekt, der beim chinesischen Hamster die Entwicklung eines diabetischen Syndroms zur Folge hat, die Biosynthese des Insulins betrifft.

Key-words: Diabetes in animals, chinese hamster, cricetulus griseus, ketotic diabetes, islet of Langerhans, $\beta$-cells. B-cells, B-cell volume, conjugal diabetes, offspring of diabetics.

\section{Introduction}

Data accumulated from long-term records on the incidence of diabetes in offspring of chinese hamsters with genetic diabetes have become available [12]. From these histories, it is pertinent that when two ketotic diabetic chinese hamsters are mated, 54 per cent of the offspring of the mating exhibit glycosuria at 21 days of age; with time the incidence increases so that at eight months, 100 per cent of the offspring are diabetic. Using quantitative technics developed in our laboratory [20], we have shown a diminution in beta cell volume in asymptomatic siblings of diabetic chinese hamsters [6]. Although light $[23,22,1,2]$ and electron $[5,3,4,21]$ microscopic investigations of islet tissue have been reported in this species, none of these included quan- titation. Further, neither ketotic animals nor their offspring have been examined microscopically. We felt, then, that application of quantitative technics to the morphology of the islets in the asymptomatic offspring of severely diabetic hamsters and in ketotic diabetic hamsters of varying ages might contribute to the evaluation of the genetic factors influencing diabetes.

\section{Materials and Methods}

Animals. The animals were maintained and mated in the colony at the Upjohn Company, Kalamazoo, Michigan. In those cases where the male and female animals mated were severely ketotic diabetic hamsters, the mating will be designated K-K. The animals were grouped as follows: [14] 15-day-old asymptomatic wean- 
lings (K-K) defined as potentially diabetic because they were sacrificied before clinically manifest diabetes usually develops, [20] three- and six-month-old animals ("younger ketotics") and [6] animals ten to 19 months of age ("older ketotics"). In the latter two groups, each animal had hyperglycemia, glycosuria and ketonuria. For convenience, these three groups will be called "experimental" although no experimental procedures were performed; further, only in groups two and three were the animals diabetic.

Each animal in these "experimental" groups was matched with a control of identical age: their parents were non-diabetic, non-related chinese hamsters.

Clinical Data - At Kalamazoo, the following clinical data were obtained biweekly: Testape and Ketostix records and blood glucose concentration. In addition, plasma insulin and blood glycerol levels were studied one week before the scheduled time of sacrifice. Twenty-four-hour urine glucose excretion was determined daily each of the seven days preceding death. During this period, intake of food and water were not restricted.

Before decapitation, the weanlings were separated from their mothers - "fasted" - four hours whereas the other animals were fasted overnight. The data obtained at sacrifice included: body weight, as well as concentrations of blood glucose [7], plasma insulin $[27,28]$, blood glycerol [19], and blood ketone [26]. All animals were decapitated between 8 and 10 a.m.

Histologic Technic - The pancreas was dissected; after its total weight was recorded, a section from the splenic end was fixed for electron microscopy. In addition, a small sample of tissue from selected animals was fixed in cold Deane's fluid to permit assessment of glycogen deposition in the islets after a periodic acid Schiff staining technic.

When the remainder of the pancreas was weighed again, it was placed in aqueous Bouin fixative for four hours. After the tissues were double infiltrated (in celloidin and paraffin), they were embedded in paraffin. Each tenth section, four microns in thickness, was mounted and stained with our modification of Gomo. ri's aldehyde fuchsin-ponceau [13]. In addition, adjacent sections were stained with chrome hematoxylinphloxine (i.e. sections 9, 19 etc.) [14] while others (section 11,22 etc.) were stained with silver [16].

Quantitation - With low power objectives on the light microscope micrometer component quantitator (LMCQ) [20], islet volume was obtained. The traverse interval was $0.5 \mathrm{~mm}$. Then, fifteen islets from each pancreas were quantitated using the LMCQ with oil immersion objectives; the traverse interval was $0.2 \mathrm{~mm}$.

The aldehyde fuchsin positive cells (beta cells) were subdivided into several classes: in those beta cells denoted as $4+$, the cytoplasm was filled with granules; in the $2+$ cells, the density of granules was half that of the fully granulated $(4+)$ cells; only a few granules were seen in those cells designated as $1+$. When the cytoplasm was lilac tinged but without granules, the cells were designated non-granular. Alpha cells and blood vessels were included in the quantitation. (For examples of the cells, see the color plate in our previous publication [6]).

For each of the components of the islets, average intercepts were calculated by dividing the millimeters of scan over a component by the number of times that component was encountered in the course of the scan. Thus, the average intercept is smaller than the average diameter of the cell or vessel being scanned.

Electron Microscopic Technics - Small portions of the splenic end of the pancreas were minced and fixed in osmium tetroxide [24]. They were embedded in epon

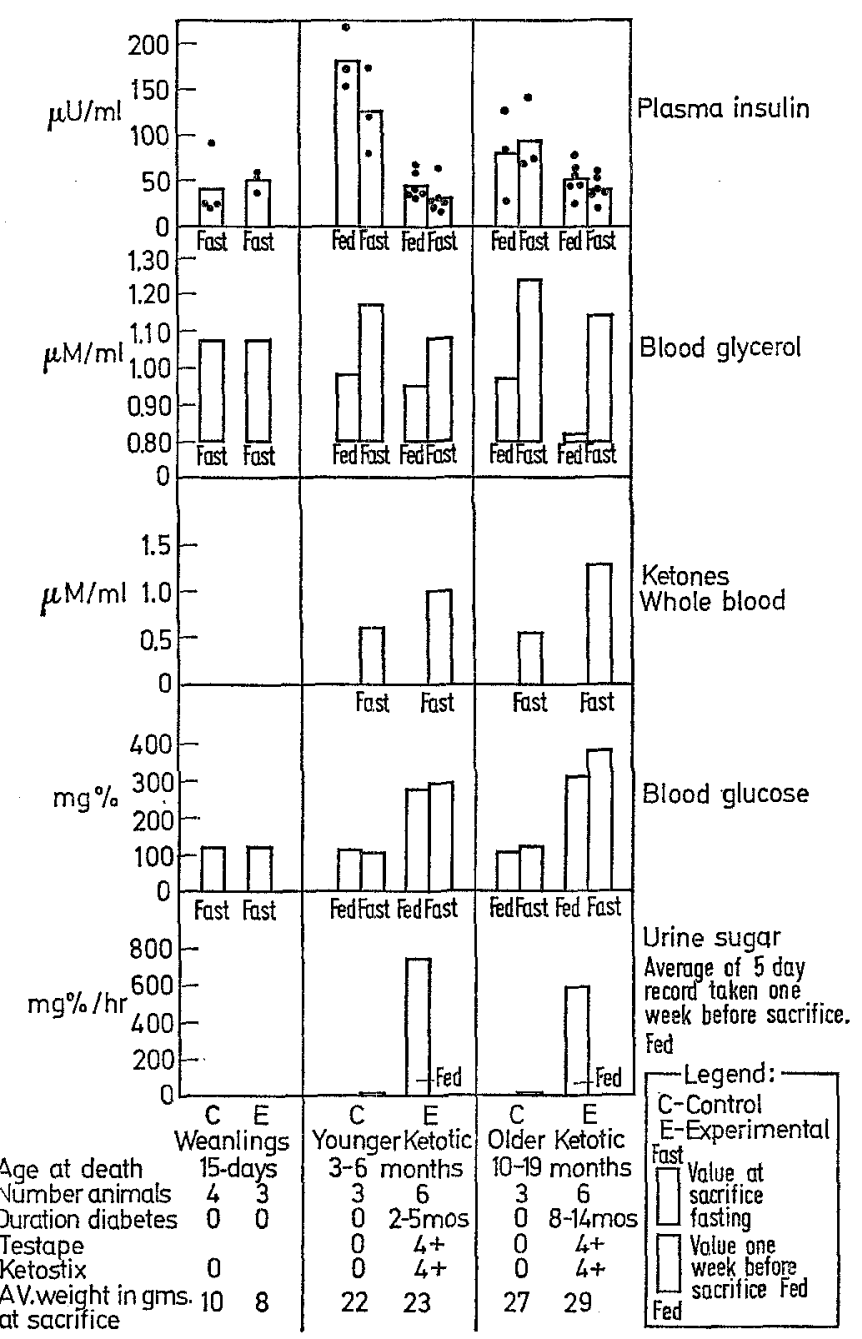

Fig. 1. Clinical data

[11], sectioned with gless knives on a Porter-Blum ultratome and examined, unstained, using $50 \mathrm{KV}$, at an RCA EMU 3G Electron Microscope equipped with a low magnification pole piece. In general, one quarter of an islet fills the field (magnification $1320 \times$ ). Each frame of the $2 \times 2$ film strip, enlarged four and onehalf times (magnification $5880 \times$ ) was printed on $8 \times 10$ paper; from these, selected fields were enlarged 
20 times (magnification $26,400 \times$ ) for quantitating the organelles of the cells on the electron micrograph component qauntitator $(2$; the model has been modified to include electric circuitry and electronic read-out tubes).

\section{Results}

A. Clinical Data (Fig. 1)

1. Weanlings. Clinical data for the weanlings $(\mathrm{K}-\mathrm{K})$ do not differ significantly from those of their controls in as much as the fasting plasma insulin (range 38$59 \mu \mathrm{U} / \mathrm{ml}$ ), blood glucose (range $105-125 \mathrm{mg}$ per cent) and blood glycerol (range $0.88-1.26 \mu \mathrm{M} / \mathrm{ml}$ ) levels are comparable; none of these animals exhibited glycosuria.

2. Younger ketotic diabetic hamsters. Each of the six diabetic animals had two or more testape and one or more ketostix records graded $4+$. In all six of the diabetic animals in this group the blood glycerol and plasma insulin levels were low. These tests merit a more critical examination; further the levels when the animals were feeding should be compared with fasting levels obtained at sacrifice. The average concentration of urinary glucose during the five-day period, one week before sacrifice, was $746 \mathrm{mg}$ per $100 \mathrm{ml}$ per day (the range was $150-1310 \mathrm{mg}$ per $100 \mathrm{ml}$ ). Blood glucose concentrations obtained when the animals were feeding averaged $275 \mathrm{mg}$ per cent; except for one animal, fasting values were slightly higher, averaging $292 \mathrm{mg}$ per cent. Among the controls, the average fasting blood sugar level was slightly lower $(99 \mathrm{mg}$ per $100 \mathrm{ml}$ ) than that $(106 \mathrm{mg}$ per $100 \mathrm{ml})$ of fed animals. Ketone levels determined on whole blood were drawn only at sacrifice when the animals were fasting; the average value for the diabetics, $1.0 \mu \mathrm{M} / \mathrm{ml}$, was 68 per cent higher than that of the controls.

Fasting blood glycerol values averaged $1.08 \mu \mathrm{M} / \mathrm{ml}$ in the younger ketotic animals as compared to an average of $1.17 \mu \mathrm{M} / \mathrm{ml}$ for their controls. Values were somewhat lower when the animals were fed $(0.95 \mu \mathrm{M} / \mathrm{ml}$ compared with an average of $0.98 \mu \mathrm{M}$ among the controls). Fasting plasma insulin levels were also lower (average $30 \mu \mathrm{U} / \mathrm{ml}$ ) among the younger ketotics than among the controls (average $125 \mu \mathrm{U} / \mathrm{ml}$ ). The plasma insulin levels in fed animals were higher than the fasted (diabetics averaged $43 \mu \mathrm{U} / \mathrm{ml}$; the controls averaged 182). The average difference in plasma insulin levels among the younger diabetics (average fasting value of 30 compared to an average of 43 in fed animals) was $13 \mu \mathrm{U} / \mathrm{ml}$; among the controls, values of 125 fasting and 182 feeding represent an average change of 57 $\mu \mathrm{U} / \mathrm{ml}$.

3. Older ketotic diabetic animals. The older ketotic diabetic animals were killed at 10 to 19 months of age; in five of the six diabetic animals, glycosuria was observed between two and six weeks after birth but in one animal (PF7-8) glycosuria appeared at five months of age. Seven or more testape records were graded $4+$; two or more ketostix were graded 3 to $4+$ which implies excretion of more than $15 \mathrm{mg}$ of
$\mathrm{B}-\mathrm{OH}$ butyric acid in $24 \mathrm{~h}$. These animals had marked hyperglycemia with decreased plasma insulin and blood glycerol levels. The fasting blood ketone levels were 140 per cent higher than those of the control animals.

Excretion of glucose averaged $596 \mathrm{mg}$ per 100 $\mathrm{ml}$. The concentration of blood glucose in the older ketotic diabetic animals during fasting averaged $386 \mathrm{mg}$ per $100 \mathrm{ml}$ whereas the controls averaged $119 \mathrm{mg}$ per $100 \mathrm{ml}$; the values were somewhat lower when the animals were fed (average $312 \mathrm{mg}$ per $100 \mathrm{ml}$ among the diabetics and $108 \mathrm{mg}$ per $100 \mathrm{ml}$ in their controls). The fasting blood ketone levels of the older ketotic animals averaged $1.2 \mu \mathrm{M} / \mathrm{ml}$ while the controls averaged $0.54 \mu \mathrm{M} / \mathrm{ml}$.

Blood glycerol levels of fasted animals were higher $(1.14 \mu \mathrm{M} / \mathrm{ml})$ than those of the fed animals $(0.82 \mu \mathrm{M} / \mathrm{ml})$; the corresponding values in the controls were 1.24 $\mu \mathrm{M} / \mathrm{ml}$ in fasting and $0.97 \mu \mathrm{M} / \mathrm{ml}$ in fed animals. Plasma insulin levels were lower in diabetic animals than in the controls; the concentrations in the diabetic animals that were feeding were higher than those of the fasted animals-average $51 \mu \mathrm{U} / \mathrm{ml}$ in the former compared with an average of $40 \mu \mathrm{U} / \mathrm{ml}$ in the latter. In contrast to the values at three to five months of age, the blood insulin levels in the fed controls $(78 \mu \mathrm{U} / \mathrm{mI})$ were lower than the values obtained in fasted control animals $(93 \mu \mathrm{U} / \mathrm{ml})$.

No significant differences were observed in the weights of the animals in the control or experimental groups at any age.

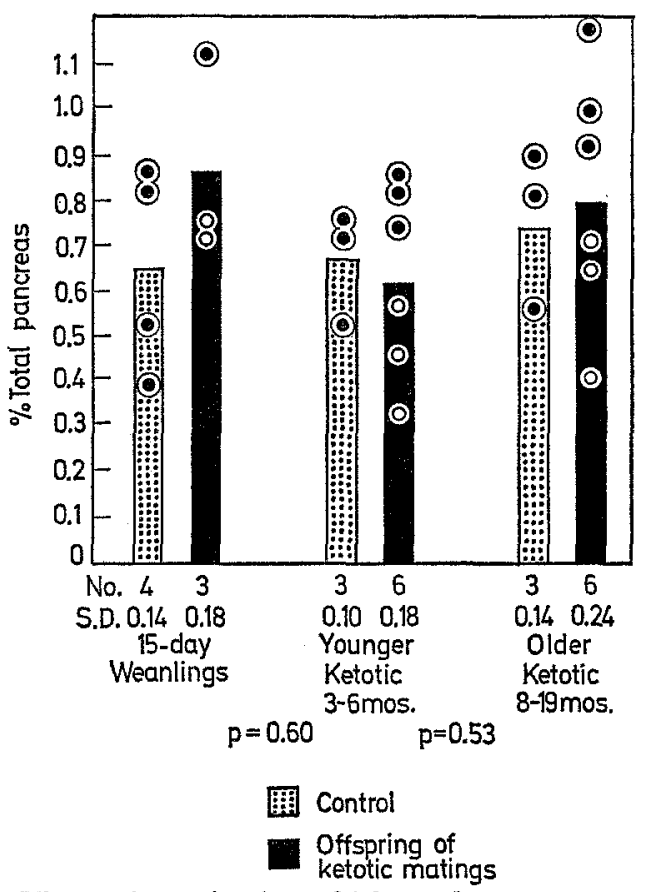

Fig. 2. Quantitation of islet volume

\section{B. Islet Volume}

In Fig. 2 are shown the results of quantitation of the pancreas for islet volume. The average islet volume 
for all animals was 0.71 per cent of the total tissue of the pancreas. The values reported for the ketotic diabetic animals approximate those of the controls in the three groups studied.

\section{C.Volume of the Components of the Islets}

In Fig. 3, the results of the quantitation of the components of islets - beta cells, alpha cells and blood vessels - are represented as a percentage of the total islet. In the control groups the beta cells, which are preponderantly fully granulated $(4+)$, average 75 per cent of the total islet volume while alpha cells comprise 18 per cent and vessels, 7 per cent.

In each of the three experimental groups, there is a diminution of fully granulated beta cells and a resultant reciprocal increase in sparsely granulated beta cells. It is noteworthy that the beta cells of the asymptomatic weanlings of ketotic parents exhibit a loss in beta granulation and also that only 23 per cent of the cells of the islets are fully granulated. Fifteen per cent of the cells of islets in the younger ketotics are fully granulated; the value for older ketotics averages one per cent. Partially granulated beta cells ( 3 to $2+$ ) average 20 per cent in the K-K weanlings, 20 per cent among the diabetic animals three to six months of age

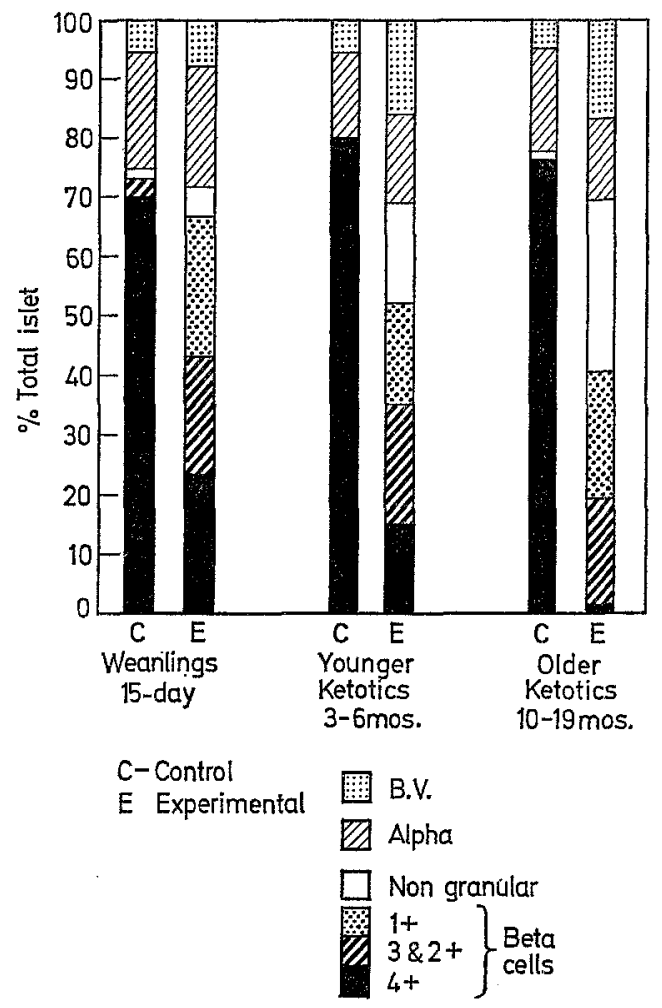

Fig. 3. Quantitation of islet components

and 18 per cent among the older diabetic animals; the sparsely granulated $(1+)$ cells average 23,17 and 22 per cent in these groups. Of particular interest are the so-called non-granular cells; the increase in volume of these cells is progressive with duration of diabetes there being only four per cent in the K-K weanlings, 16 per cent in younger diabetios but 29 per cent in the older ketotic diabetic animals. If the non-granular cells were included as beta cells, the total volume of beta cells would approximate 70 per cent in each of the groups of experimental animals.

The percentage of blood vessels in the islets of the younger and older ketotic animals is increased as seen by comparison with either the K-K weanlings or with the control groups. When the percentages of alpha
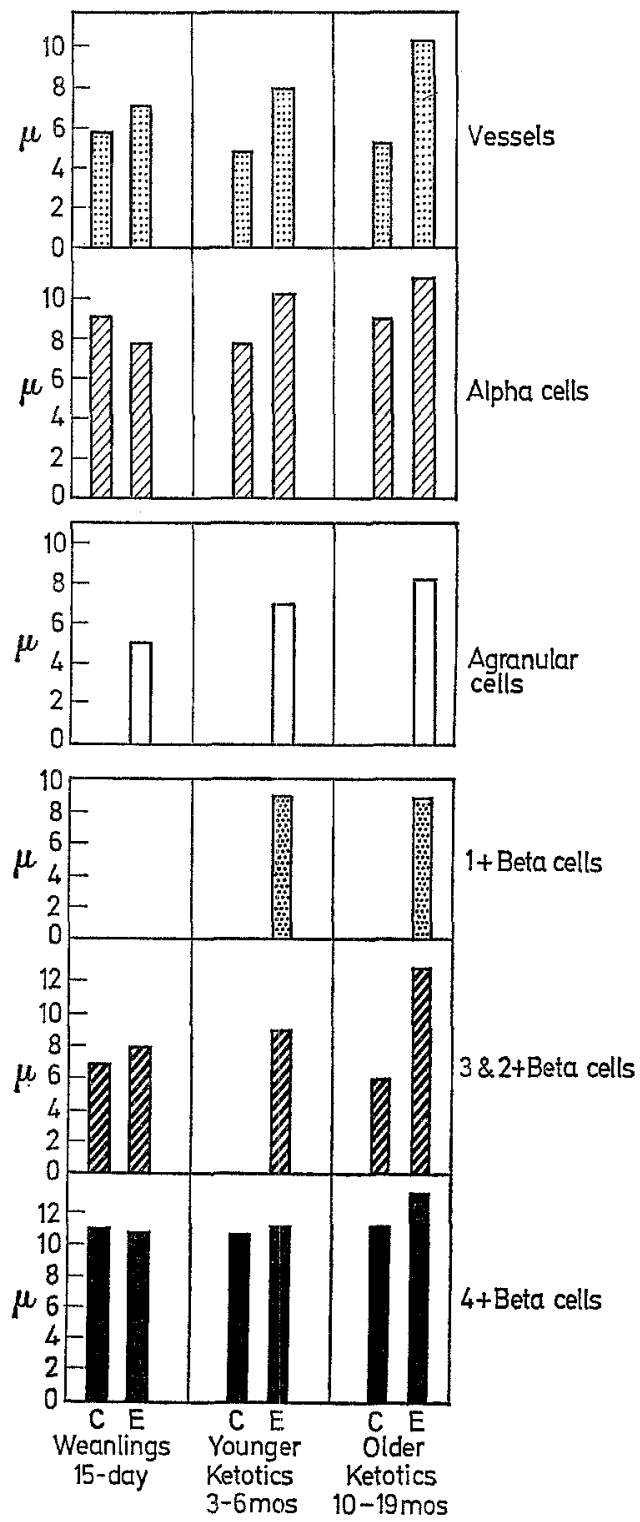

Fig. 4. Average intercepts of components of islets

cells (using the aldehyde fuchsin stain) are compared, there are no differences attributable either to the diabetic state or to age; alpha cells averaged 17 per cent of the islet volume. 
In Fig. 4, average intercepts over each of the components of the islets are recorded. Among control animals, no differences related to age were found in any of the normal components (fully granulated beta cells, alpha cells or blood vessels).

There are increases in the average intercept, with age and/or duration of diabetes, in all of the components of the islets of ketotic diabetic animals, but especially in fully $(4+)$ and partially $(2$ to $3+$ ) granulated beta cells as well as in the vessels of the islets. Small increments in average intercept correspond to sizable changes in volume; for example, if one compares the average intercept of fully granulated $(4+)$ beta cells (10.8 $\mu$ in the control and $13.1 \mu$ in the older ketotics) with their respective volumes - assuming the shape to be a sphere - the cells of the older ketotic animals are 65 per cent greater in volume. This increase in volume might result from the deposition of glycogen because two to three grams of water are stored with each gram of glycogen deposited.

Another point of interest is the relationship of the volume of each component to the average intercept. Thus, although the average intercept over fully granulated $(4+)$ beta cells in the older ketotics is $13.1 \mu$, only one per cent of the volume consists of such cells.

It is noteworthy, too, that as the cells degranulate, their average intercept is smaller. Whereas, in older ketotic hamsters, the average intercept over the 2 to $3+$ beta cells is $12 \mu$, the intercept over $1+$ beta cells is $8 \mu$ and the latter cells represent 21.6 per cent of the volume of the islet. Further, these small cells do not occur in islets of control animals.

\section{Periodic Acid Schiff and Silver Stains}

Using the PAS stain on selected Deane-fixed sections, glycogen infiltration was noted in the islets of the animals of the experimental groups. The deposition was sparse (averaging 2.4 cells per islet) and finely granular in the weanling of the ketotic mating. It was more abundant in the younger and older ketotic diabetic animals averaging 3.3 cells per islet in the former and 8.7 cells per islet in the latter where the deposition was in the form of lakes.

In the control groups there was an average of 6.5 silver positive cells per islet. In the $K-K$ weanling there were 7.8 silver positive cells per islet. Silver positive cells in each islet of the younger ketotic animals averaged 13.2 cells; the value increased to 16.1 cells in the islets of the older ketotic diabetic animals.

\section{E. Electron Microscopy}

Preliminary data (Table 1) from quantitation of electron micrographs of islets show that in the K-K weanling, there is a diminution of both beta granule and mitochondrial volume. In addition there are smaller average intercepts over beta granules and mitochondria. In the younger ketotic offspring, too, the volume of beta granules and the average intercept over beta granules is decreased; the volumes of mito- chondria in control and experimental animals are comparable. The average volume of beta granules in the controls is 2.5 times that of the older ketotics, but the volume of mitochondria is somewhat higher in the experimental animal than in the control.

Table 1. Quantitation of the organelles of $\beta$-cells as volume percentage of total cytoplasm

\begin{tabular}{|c|c|c|c|c|c|c|}
\hline & $\begin{array}{l}15 \text { day } \mathrm{C} \\
\mathrm{K} \cdot \mathrm{K}\end{array}$ & $\mathrm{C}$ & $\begin{array}{l}3-6 \\
\text { mos. }\end{array}$ & $\mathrm{C}$ & $\begin{array}{l}10-19 \\
\text { mos. }\end{array}$ & $\mathrm{C}$ \\
\hline No, animals & 2 & & 1 & 1 & 1 & 1 \\
\hline Beta granules & 2.7 & 4.0 & 2.4 & 5.6 & 2.5 & 6.1 \\
\hline Mitochondria & 8.3 & 10.0 & 6.6 & 5.9 & 6.2 & 5.2 \\
\hline
\end{tabular}

Another point of interest is the change that occurs with age. Evaluation of the control animals suggests that the granule volume increases with age. The asymptomatic $\mathrm{K}-\mathrm{K}$ weanlings and the diabetic animals have beta granule volumes that vary little with age.

While studying the individual cells in the micrographs of one of the younger diabetic animals, it was found that some eight per cent of the total scan traversed non-granular cells; considering that an electron micrograph represents only one-fourth the area of a section of islet, this value compares favorably with the 13 per cent agranular cells quantitated using light microscopy.

\section{F. Beta Cell Index}

1. Definition. The mean quantity of beta cell granulation per islet was calculated by multiplying the percentage of the various aldehyde fuchsin-positive cells by a factor [14, 20 or 23] relating to the degree of posi-

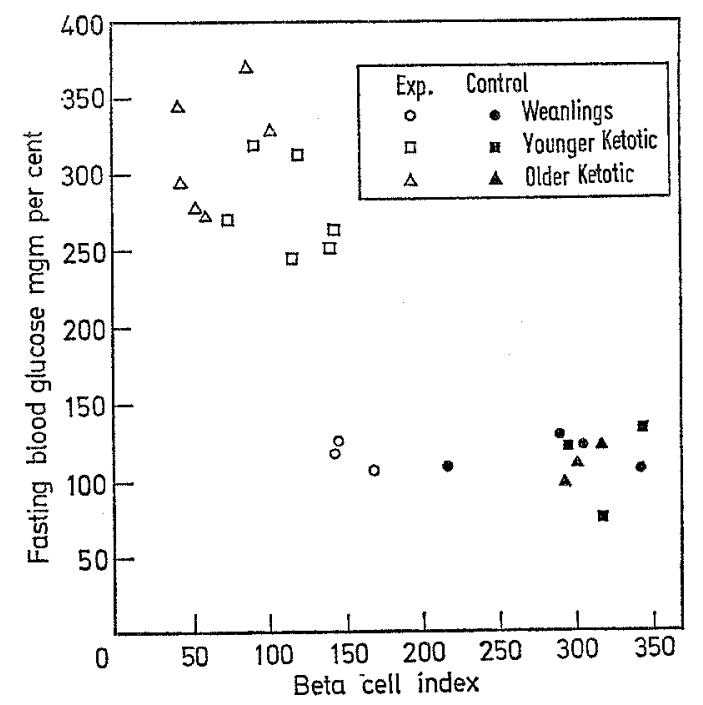

Fig. 5. Beta cell index: Blood glucose

tive staining; the sum of these values divided by 100 is the beta cell index.

2. Correlation with blood glucose values. In Fig. 5, it is evident that low blood glucose values and high beta 
cell indices are characteristic of the control animals. Among the diabetic hamsters, the beta cell indices are low but the blood glucose levels are high. However, the normoglycemic K-K weanlings have a depression in beta cell index.

3. Correlation with plasma insulin levels (Fig. 6). The 15-day-old control animals tend to have low plasma insulin levels despite high beta cell indices. All of the other control animals have high beta cell indices and high fasting plasma insulin levels. Among the diabetic animals, there is, in general, a correlation between beta cell index and plasma insulin level in that both values are low. Further, the values for control and diabetic animals do not overlap. It is of particular interest that the 15-day-old K-K weanlings have higher plasma insulin levels than three of their four controls (see also

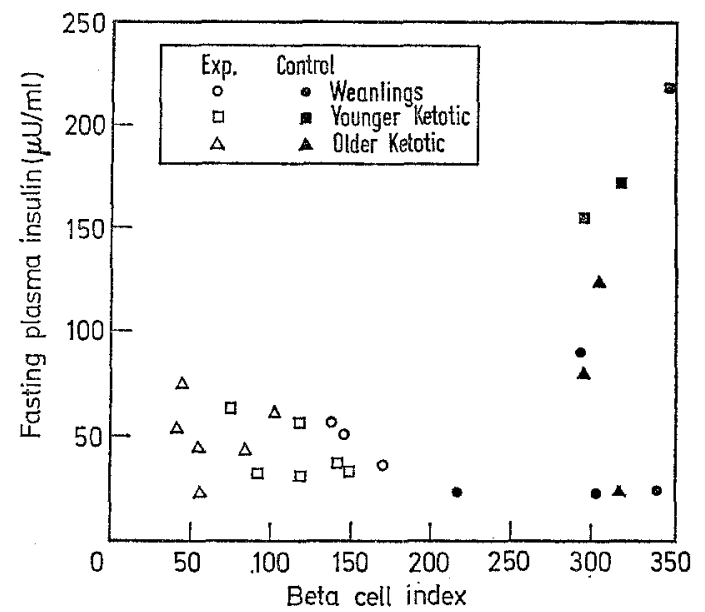

Fig. 6. Bota cell index: Plasma insulin

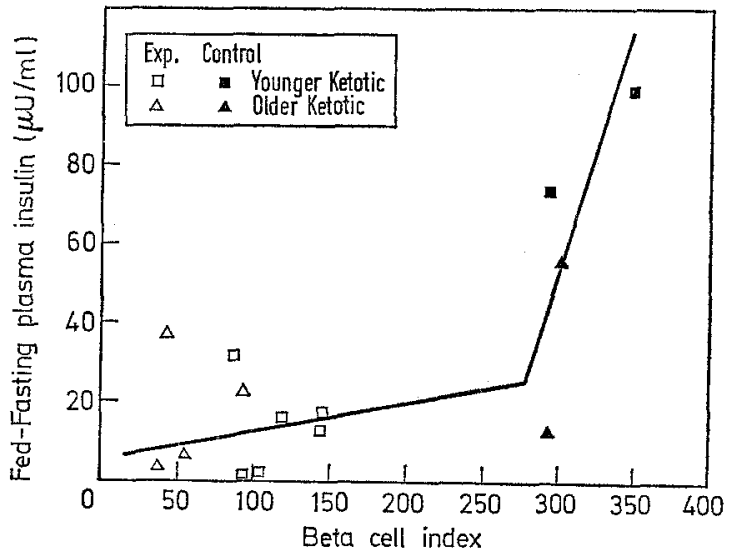

Fig. 7. Beta cell index: Fed-fasting plasma insulin levels

Fig. 1) and the fasting insulin concentrations of the weanling controls are lower than the values recorded for the controls in the two older age groups.

4. Plasma insulin levels in fasted and fed animals. It has been pointed out that plasma insulin levels of feeding animals usually are higher than those of fasting animals. This was true for four of the six control ani- mals and for 10 of the 12 diabetic animals. In Fig. 7, the difference between the fed and fasting plasma insulin levels was plotted against the beta cell index. In general, beta cells of diabetic animals secrete little insulin in response to feeding. The two ketotic diabetic animals with lowest response $(2 \mu \mathrm{U} / \mathrm{ml})$ not only were ketonuric for longer periods than the other animals but they were also the progeny of K-K matings.

In the control animals, the response to foeding averages three times that observed in the diabetic animals. One control animal (Cul-4, 10.5 months old) showed little response after feeding; its male parent

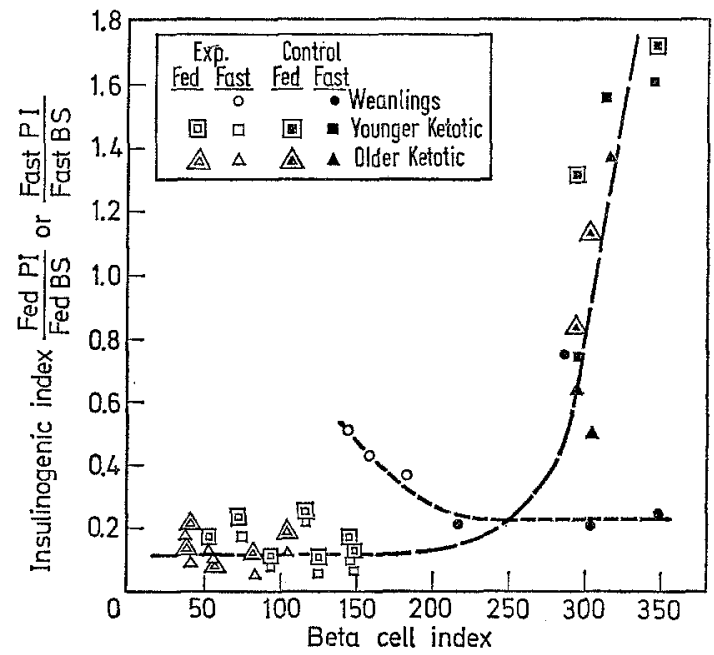

Fig. 8. Insulinogenic index: Beta cell index

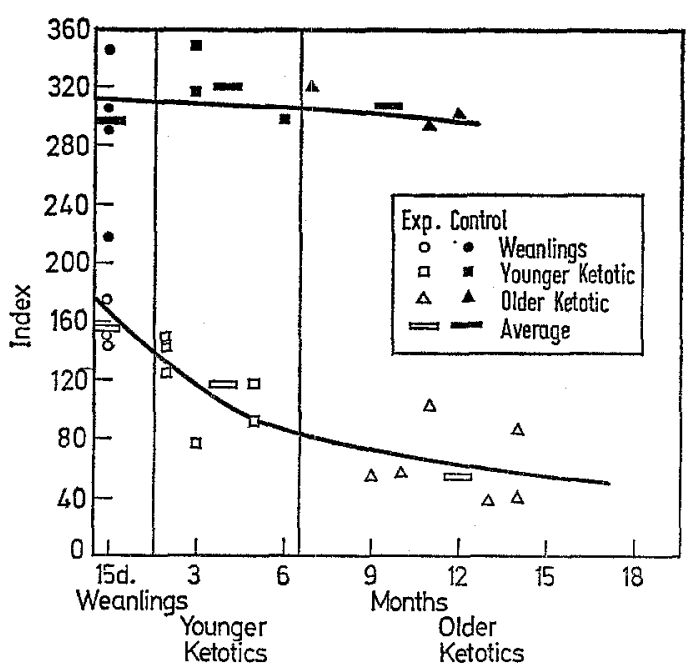

Fig. 9. Beta cell index: Duration of diabetes

was a non-diabetic from the Upjohn colony and the mother was from the Canadian colony.

5. Correlation of insulinogenic index with beta cell index (Fig. 8). The insulinogenic index [25] is directly related to the beta cell index. The weanling controls have the lowest indices. Average beta cell and insulinogenic indices of control animals three to six months 
of age are higher than those of the older animals. Indices for all of the diabetic animals are clustered together.

The K-K weanlings are unusual in having higher insulinogenic indices but lower beta cell indices than their controls. At 15 days of age, there appears to be an inverse relationship between beta cell index and insulinogenic index.

6. Correlation with duration of diabetes (Fig. 9). When the beta cell indices are plotted against duration of diabetes, the average value (311) for the three groups of control animals changes little with age. Among the offspring of diabetic animals, however, the $\mathrm{K}-\mathrm{K}$ weanlings have an index that is lower than that of the controls. The diminution in beta cell index is progressive with the duration of diabetes. Animals that have had diabetes for one year have an average beta cell index which is one-fifth that of a normal animal of the same age.

\section{Discussion}

In this paper, the results presented for the younger and older ketotic diabetic chinese hamsters are consistent with those reported previously [6]. Clinically the animals had glycosuria, elevated blood ketones, hyperglycemia, low blood glycerol levels, low plasma insulin levels, and a decreased insulin secretory response (comparison of fed and fasting plasma insulin levels).

Because the total islet volume in ketotic diabetic animals, 3 to 19 months of age, approximated that of the control, loss of beta cell mass has not been considered a prominent feature of this disease. The values for pancreatic islet volume in the chinese hamster published previously (3, Fig. 2) indicated that both the diabetic animals as well as their nondiabetic siblings had a reduced islet volume (the values were not statistically significant) when compared to a group of non-related non-diabetic chinese hamsters. In these control animals, the total islet volume averaged 1.7 per cent of the pancreas; this value is much higher than that found in the control non-diabetic subline (0.74 per cent) that is in current use. Indeed, the islet volume of the present subline of non-diabetic chinese hamsters closely approximates that reported for the non-diabetic siblings.

In the diabetic animals of the present study, the volume of fully granulated beta cells decreased, there was glycogen infiltration in beta cells and the volume of vessels in the islet was increased. The volume of both partially granulated beta cells and non-granular cells increased progressively both with increased duration and severity of diabetes. By electron microscopy, the degree of granulation of the beta cells paralleled that quantitated using light microscopy. The average size (indicated by the length of the intercept) of the secretion granule was smaller in the diabetic than in the normal.
Of particular interest, however, is the observation of morphologic change, i.e. diminished beta cell granulation in 15-day-old offspring of two severely ketotic animals, at a time prior to any clinical sign of diabetes. In addition, the islet volume was somewhat elevated. Although hyperglycemia and glycosuria were absent, both plasma insulin levels and insulinogenic index were elevated.

The cells devoid of aldehyde fuchsin positivity have not been characterized adequately. In diabetes, a significant volume (average of 15 to 30 per cent) of the total islet volume consists of non-granular cells; at the light microscope, their cytoplasm has a pale violet hue when aldehyde fuchsin is used as the stain. By electron microscopy there are cells without grauules which lack, as well, characteristics either of alpha or beta cells. If these non-granular cells do not have the capability of synthesizing insulin, then there is a moderate reduction in the total mass of beta cells (from 72 to 43 per cent of the islet volume) as we reported previously. If on the other hand, the non-granular cells are capable of insulin biosynthesis, despite the absence of granulation, then their inclusion would raise the total mass of beta cells to a value approximating that of the controls.

If the non-granular cells are beta cells, despite their lack of stored end product, they might be able to store insulin after the establishment of normoglycemia resulting from insulin therapy. The non-granular cells should disappear and the percentage of granulated beta cells should increase when the hyperglycemia is controlled by insulin. This study is being carried out. It might be possible to establish the identity of the nongranular cells by electron microscopy using lead hydroxide stains to visualize glyoogen. By light microscopy there was no evidence of glycogen infiltration in non-granular cells nor did the number of cells with glyoogen deposition correspond to the number of agranular cells.

Extensive glycogen infiltration was observed, however, in the cytoplasm of a few of the beta cells in animals with severe diabetes, but glycogen infiltration was not a characteristic finding in most of the beta cells with decreased granulation. A few of the cells in the asymptomatic weanling hamsters were infiltrated with glycogen but none of the agranular cells evidenced glycogen deposition.

There is no overlap in the values of beta cell index between the diabetic hamsters and their controls (see Fig. 8). One of the control animals (index $=230$ ) was aberrant in that its index was intermediate between that of the diabetic and control groups; this animal, of a non-diabetic father (Upjohn colony) and a mother from the Toronto colony, may have been a potentially diabetio hamster that would have developed diabetes later in life had it survived.

There is an inverse relationship between beta cell index and the level of blood glucose. The beta cell index, a cytologic measure of insulin content, parallels closely the insulinogenic index, a physiologic measure of insu- 
lin secretion. Both the beta cell index and the insulinogenic index are decreased in diabetic animals. The insulin secretory capacity (measured by the insulinogenic index) of the diabetic animals 10 to 19 months of age was approximately one-tenth that of the controls of corresponding age. Both indices show a progressive decrease with increasing duration of the diabetes.

The fall in plasma insulin levels with the development of manifest diabetes could result from interference with insulin biosynthesis. The somewhat elevated blood insulin levels in the K-K weanlings might reflect an initial over-stimulation of the beta cell in those animals that would, doubtless, have developed. diabetes by the third week had they survired.

These quantitative studies on the morphology of the islet cells and subcellular components in the diabetic chinese hamster are consistent with the thesis that the primary lesion is the result of a block (or failure) in insulin biosynthesis. In turn, this would result in decreased quantity of stored insulin in the beta cell as evidenced cytologically by a decreased beta granulation which was observed at both the light and electron microscope level; it is evident at a time when hyperglycemia or glycosuria are absent. With increasing severity of the diabetes, there should be a correspondingly greater decrease in the beta cell granulation (evidenced by fewer fully granulated beta cells), an increased number of partially granulated beta cells, and the possible appearance of significant numbers of agranular cells. By electron microscopy there could be a decreased size of the beta cell granule. These changes have been observed and the degree of beta granule depletion was greater in diabetic animals sacrificed at nine to 19 months than at three to six months.

Recent findings [10] indicate that toadfish islet tissue is characterized by a stereospecific glucose transport mechanism. It has been suggested, too, that a primary defect at the glucose transport site would result in diabetes. If the ketotic diabetic chinese hamster has a genetic defect at the glucose transport site within the beta cell membrane, all of our observations would be explained. The impairment at the glucose transport site is envisioned as a partial block rather than as a complete absence of the sterospecific glucose transport mechanism. Since glucose stimulates insulin biosynthesis [18] a block in glucose transport could be the consequence of a diminished intracellular glucose concentration and a decreased rate of protein synthesis.

Chang [8] incubating isolated islets in media containing two labeled isotopes measured protein biosynthesis. His findings suggest that the islet tissue of a diabetic has a specific block in insulin biosynthesis whereas other proteins may be synthesized at a normal rate.

Since increasing the blood glucose level stimulates the beta cell to release insulin, a primary defect in the glucose transport mechanism should be reflected in a diminished insulin secretory response. Consequently blood insulin levels in the diabetic animal should be considerably lower than that of control. Similarly, blood insulin levels following glucose administration (in a glucose tolerance test) would be lower in the diabetic than in the control animals. The diabetic chinese hamster would, thus, be characterized by an insulin deficiency; all of the symptoms observed would be secondary to the diminished availability of insulin at the various target sites.

Although a defect in the glucose transport mechanism could explain the observations, a similar defect in amino acid transport could account for the symptoms as well. Cooperstein and Lazarow [9] in their studies on the uptake of amino acids in the toadfish islet tissue have obtained evidence for a number of independent amino acid transport mechanisms which also could result in a diminished insulin biosynthesis and decreased numbers of beta granules.

Since permeability studies similar to those reported in the toadfish can be carried out using islet tissue isolated from chinese hamsters, it should be possible to determine whether the glucose or amino acid transport mechanism is the primary cause of diabetes in this species.

It should be emphasized that decreased insulin biosynthesis could be the result of an assortment of blocks at various subcellular sites which might include the following: a defective amino acid activation system could result from an enzymatic defect in any of the specific amino acid activating enzymes essential for proinsulin biosynthesis; a defective RNA replication mechanism resulting in diminished amounts of transfer, messenger or ribosomal RNA; a block in the conversion of proinsulin to insulin; an impaired "packaging mechanism" resulting in a failure of the newly synthesized protein to concentrate within the cisternae of the endoplasmic reticulum or to transfer to the Golgi complex where it would be converted to a definitive secretion granule.

Blood insulin levels in the 15-day-old offspring of ketotic diabetic parents were higher than those observed in the controls. At a time prior to the appearance of glycosuria or hyperglycemia, these results are not readily explained unless they might be the result of counter-regulatory forces brought into play by control mechanisms acting on the beta cell. The transitory increase in blood insulin levels at 15 days could be due to an increased secretion of growth hormone, ACTH, or glucagon. If the secretory activity of either the pituitary, hypothalamus or pancreatic alpha cells is dependent upon the blood insulin levels then they would respond (to a diminished availability of insulin) by increasing their secretion which in turn would secondarily increase the output of insulin by beta cells. Although the beta cells might be able to respond over a short interval, by secreting more insulin, they presumably are unable to maintain the insulin levels so that eventually the blood insulin levels fall to values below 
those of the normal. We are suggesting that pituitary (and/or hypothalamic and/or the alpha) cells respond to a low blood insulin level by secreting increased amounts of hormone (growth, ACIH or glucagon).

It should be emphasized that many of the characteristics of diabetes in the genetically controlled spontaneous diabetic chinese hamster approximate closely those seen in human diabetes of "maturityonset" type ( $>20$ years). The islets contain granulated beta cells but they are present, usually, in decreased numbers. Although the insulin content of the pancreas is often reduced, it may approach that of the normal [15]. The beta cells have a decreased secretory response to glucose [7]. By contrast, in most other forms of spontaneous diabetes in animals, i.e. the $d b$, spiny, obob and K-K mice as well as in the Egyptian sand rat, islet hyperplasia and increased size of the islets are a prominent feature of the disease. Our findings suggest the possibility that "maturity-onset" type of diabetes in humans may be due to a genetic defect in the glucose transport site of the beta cell membrane.

Acknowledgements: The work was supported from grants USPHS AM 6517 and AM 5127 as well as a generous gift from the Upjohn Company.

It is a pleasure to cite the excellence of the technical staff without whom this research would have been impossible; gratitude is extended to Miss Janet Whitley, Miss Catherine Sulik and Mrs. F.L. Schmidt. Gregory Nelson encountered new horizons in this his first venture into research.

\section{References}

1. Boquist, L.: Morphology of the pancreatic islets of the nondiabetic adult Chinese Hamster, Cricetulus griseus. Light microscopical findings. Acta Soc. Med. upsalien. 72, 331-334 (1967)

2. - Alloxan administration in Chinese Hamster. I. Blood glucose variation, glucose tolerance, and light microscopical changes in pancreatic islets and other tissues. Virchows Arch. Abt. B Zellpath. 1, 157-168 (1968).

3. - Alloxan administration in Chinese Hamster. II. U1trastructural study of degeneration and subsequent regeneration of pancreatic islet tissue. Virchows Arch. Abt. B Zellpath. 1, 169-181 (1968).

4. - Cilia in normal and regenerating islet tissue. An ultrastructural study in the Chinese Hamster with particular reference to the beta cells and the ductular epithelium. Z. Zellforsch. 89, 519-632 (1968).

5. - Morphology of the pancreatic islet of the nondiabetic adult Chinese Hamster, Cricetulus griseus. Ultrastructural findings. Acta Soc. Med. upsalien. 72, $345-357$ (1967).

6. Carpenter, A.-M., Gerritsen, G.C., Dulin, W.E., Lazarow, A.: Islet and beta cell volumes in diabetic Chinese Hamster and their non-diabetic siblings. Diabetologia 3, 92-99 (1967).

7. Cerasi, E.: Insulin response to glucose infusion in prediabetes. In: Ostman, J., Milner R.D.G.: Diabetes. Proceedings of the Sixth Congress of the International Diabetes Federation, Stockholm, Sweden, July 30 - Aug. 4, pp. 498-504., 1967. Amsterdam: Excerpta Medica Foundation 1969.
8. Chang, A.Y., Schneider, D.I.: Metabolic abnormalities in the pancreatic islets and livers of the diabetic Chinese Hamster. Diabetologia, current issue.

9. Cooperstein, S.J., Lazarow, A.: unpublished data.

10. - - Uptake of glucose by the islet of Langerhans and other tissues of the toadfish. Amer. J. Physiol, in press.

11. Finck, H.: Epoxy resins in electron microscopy. J. biophys. biochem. Cytol. 7, 27-30 (1960).

12. Gerritsen, G.C., Needham, L.B., Schmidt, F.L., Dulin, W.E.: Studies on the prediction and development of diabetes in offspring of diabetic Chinese Hamsters. Diabetologia 6, 158-162 (1970).

13. Gomori, G.: Aldehyde fuchsin: A new stain for elastic tissue. Amer. J. clin. Path. 20, 665-666 (1950).

14. - Observations with differential stains on human islets of Langerhans. Amer. J. Path. 17, 395-406 (1941).

15. Haist, R.E.: Factors affecting the insulin content of the pancreas. Physiol. Rev. 24, 409-444 (1944).

16. Hellerström, C., Hellman, B.: Some aspects of silver impregnation of the islets of Langerhans in the rat. Acta endocr. 35, 518-532 (1960).

17. Hoffman, W.S.: A rapid photoelectric method for the determination of glucose in blood and urine. J. biol. Chem. 120, $51-55$ (1937).

18. Howell, S.L., Taylor, K.W.: Effects of glucose concentration on incorporation of $\left({ }^{3} \mathrm{H}\right.$ )-leucine into insulin using isolated mammalian islets of Langerhans. Biochim. biophys. Acta 130, 519-521 (1966).

19. Laurell, S., Tibbling, G.: An enzymatic fluorometric micromethod for the determination of glycerol. Clin. chim. Acta 13, 317-322 (1966).

20. Lazarow, A., Carpenter, A.-M.: Component quantitation of tissue sections. I. Characterization of the instruments. J. Histochem. Cytochem. 10, 324-328 (1962).

21. Luse, S.A., Caramia, F., Gerritsen, G., Dulin, W.E.: Spontaneous diabetes mellitus in the Chinese Hamster. An electron microscopic study of the islet of Langerhans. Diabetologia 3,97-108 (1967).

22. Malaisse, W., Malaisse-Lagae, F., Gerritsen, G.C., Dulin, W.E., Wright, P.H.: Insulin secretion in vitro by the pancreas of the Chinese Hamster. Diabetologia $3,109-114$ (1967).

23. Meier, H., Yerganian, G.A.: Spontaneous hereditary diabetes mellitus in Chinese Hamster (Cricetulus griseus). I. Pathological findings. Proc. Soc. exp. biol. $100,810-815(1959)$.

24. Palade, G.: Study of fixation for electron microscopy. J. exp. med. 95, 285-296 (1952).

25. Seltzer, H.S., Harris, V.L.: Exhaustion of insulinogenic reserve in maturity-onset diabetic patients during prolonged and continuous hyperglycemic stress. Diabetes 13, 6-13 (1964).

26. Williamson, D.H., Melanby, J., Krebs, H. A. : Enzymatic determination of $\mathbf{D}(-)$-B-hydroxybutyric acid and acetoacetic acid in blood. Biochem. J. 82, 90-96 (1962).

27. Wright, P.H., Malaisse, W.J.: A simple method for the assay of guinea pig anti-insulin serum. Diabetolo. gia 2, 178-188 (1966).

28. Zaharko, D.S., Beck, L.V.: Studies of a simplified plasma insulin immunoassay using cellulose powder. Diabetes 17, $444 \longrightarrow 457$ (1968).

A.-M. Carpenter 254 Jackson Hall University of Minnesota Minneapolis, Minnesota 55455, USA 